Bush pressured as Nancy Reagan pleads for stem-cell research

Erika Check, Washington

Almost three years after President Bush

laid down a policy restricting the use

of public funds in embryonic stem-cell

research, calls are growing for the White

House to revisit the rules.

On 8 May, Nancy Reagan, former first lady and an icon of Bush's Republican party, spoke publicly for the first time of her support for stem-cell research. She had written letters in favour of it before but her speech, at a benefit dinner in Los Angeles for the Juvenile Diabetes Research Foundation, is seen by supporters of the research as a significant public-relations breakthrough.

Reagan said that she had been moved to support research using stem cells through watching her husband succumb to Alzheimer's disease. "Ronnie's long journey has finally taken him to a place where I can no longer reach him," she said. "We cannot share the wonderful memories of our 52 years together, and I think that is the hardest part. I am determined to do whatever I can to save other families from this pain."

A few days earlier, on 4 May, the majority leader in the Senate, Bill Frist (Republican, Tennessee), said he thought the time had come to review President Bush's policy. The rules let researchers use public funds to work on embryonic stem-cell lines only if the lines were derived before the day the policy was announced -9 August 2001.

"Momentum is building in the research done, and in Congress," says a Republican staff member for the Senate Committee on Appropriations.

Last month, 206 members of Congress, including 36 Republicans, sent a letter to President Bush asking him to expand his policy. Among its signatories were members of Congress who had previously opposed the research, such as lawmaker Dana Rohrabacher (Republican, California). Rohrabacher told reporters that he had changed his mind after hearing from patients who hope the reasearch will help cure their diseases.

A similar letter is circulating in the Senate, and White House officials have indicated that the president will meet with the authors of the House letter.

Although the National Institutes of Health estimated that researchers would be able to work on 78 stem-cell lines, fewer than 20 are actually available today. And biologists have raised doubts about the suitability of these for clinical research.
Declassified and Approved

for Release, 10 April 2004

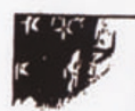

Bin Ladin Determined To Strike in US

Clandestine, forelgn government, and media reports indicate Bin Ladin since 1997 has wanted to conduct terrorist attacks in the US. Bin Ladin implied in US Ielevision interviews in 1997 and 1998 that his lollowers would lollow the example ol World Trade Center bomber Ramzi Yousel and "bring the fighting to America."

After US missile strikes on his base in Alghanistan in 1998, Bin Ladin told followers he wanted to retaliate in Washington, according to a $\mathrm{c}$ service.

An Egyptian Islamic Jihad (EIJ) operative lold an service at the same time that Bin Ladin was planning lo exploil the operative's access to the US to mount a terrorist strike.

The millennium plotting in Canarla in 1 man - ... hean part of Bin Ladin's first serious atte US. Convicted plotter ${ }^{\wedge}$. 'as in allack'

\title{
US intelligence exposed as student decodes Iraq memo
}

Declan Butler

Armed with little more than an electronic dictionary and text-analysis software, Claire Whelan, a graduate student in computer science at Dublin City University in Ireland, has managed to decrypt words that had been blotted out from declassified documents to protect intelligence sources.

She and one of her PhD supervisors, David Naccache, a cryptographer with Gemplus, which manufactures banking and security cards, tackled two high-profile documents. One was a memo to US President George Bush that had been declassified in April for an inquiry into the 11 September 2001 terrorist attacks. The other was a US Department of Defense memo about who helped Iraq to 'militarize' civilian Hughes helicopters.

It all started when Naccache saw the Bush memo on television over Easter. "I was bored, and I was looking for challenges for Claire to solve. She's a wild problem solver, so I thought that with this one I'd get peace for a week," Naccache says. Whelan produced a solution in slightly less than that.

Demasking blotted out words was easy, Naccache told Nature. "Optical recognition easily identified the font type - in this case Arial - and its size," he says. "Knowing this, you can estimate the size of the word behind the blot. Then you just take every word in the dictionary and calculate whether or not, in that font, it is the right size to fit in the space, plus or minus 3 pixels."

A computerized dictionary search yielded 1,530 candidates for a blotted out word in this sentence of the Bush memo: "An Egyptian Islamic Jihad (EIJ) operative told an service at the same time that Bin
Ladin was planning to exploit the operative's access to the US to mount a terrorist strike." A grammatical analyser yielded just 346 of these that would make sense in English.

A cursory human scan of the 346 removed unlikely contenders such as acetose, leaving just seven possibilities: Ugandan, Ukrainian, Egyptian, uninvited, incursive, indebted and unofficial. Egyptian seems most likely, says Naccache. A similar analysis of the defence department's memo identified South Korea as the most likely anonymous supplier of helicopter knowledge to Iraq.

Intelligence experts say the technique is cause for concern, and that they may think about changing procedures. One expert adds that rumour-mongering on probable fits might engender as much confusion and damage as just releasing the full, unadulterated text.

Naccache accepts the criticism that although the technique works reasonably well on single words, the number of candidates for more than two or three consecutively blotted out words would severely limit it. Many declassified documents contain whole paragraphs blotted out. "That's impossible to tackle," he says, adding that, "the most important conclusion of this work is that censoring text by blotting out words and re-scanning is not a secure practice".

Naccache and Whelan presented their results at Eurocrypt 2004, a meeting of security researchers held in Interlaken, Switzerland, in early May. They did not present at the formal sessions, but at a Tuesday evening informal 'rump session', where participants discuss work in progress. "We came away with the prize for the best rump-session talk - a huge cow-bell," says Naccache. 